Article

\title{
Study on the Effects of a $\pi$ Electron Conjugated Structure in Binuclear Metallophthalocyanines Graphene-Based Oxygen Reduction Reaction Catalysts
}

\author{
Gai Zhang ${ }^{1, *}$, Bulei Liu ${ }^{1}$, Yufan Zhang ${ }^{1}$, Tiantian $\mathrm{Li}^{2}$, Weixing Chen ${ }^{1}$ and Weifeng Zhao ${ }^{1, *}$ \\ 1 School of Materials Science and Chemical Engineering, Xi'an Technological University, Xi'an 710021, China; \\ gaomin@st.xatu.edu.cn (B.L.); zhangyufan@st.xatu.edu.cn (Y.Z.); chenwx@xatu.edu.cn (W.C.) \\ 2 Key Laboratory of Synthetic and Natural Functional Molecule Chemistry of Ministry of Education, College \\ of Chemistry \& Material Chemistry, Northwest University, Xi'an 710069, China; \\ 2015116027@stumail.nwu.edu.cn \\ * Correspondence: zhanggai@xatu.edu.cn (G.Z.); zhaoweifeng@xatu.edu.cn (W.Z.); \\ Tel./Fax: +86-029-86173324 (G.Z. \& W.Z.)
}

Received: 3 April 2020; Accepted: 9 May 2020; Published: 15 May 2020

\begin{abstract}
The high overpotentials for oxygen reduction reaction (ORR) create an extremely negative impact on the energy efficiency of the air-based battery systems. To overcome this problem, binuclear ball-type metallophthalocyanines containing methoxy substituents $\left(\mathrm{M}_{2} \mathrm{Pc}_{2}(\mathrm{EP})_{4}, \mathrm{M}=\mathrm{Fe}(\mathrm{II}), \mathrm{Co}(\mathrm{II})\right.$ and $\mathrm{Zn}(\mathrm{II})$ ) were wrapped with polystyrene sodium sulfonate (PSS) modified graphene oxide (GO), using a facilely "solvothermal $\pi-\pi$ assembly" method to prepare $\mathrm{M}_{2} \mathrm{Pc}_{2}(\mathrm{EP})_{4} / \mathrm{PSS}-\mathrm{Gr}$ composites. Compared with the commercial $\mathrm{Pt} / \mathrm{C}$ catalysts, the $\mathrm{M}_{2} \mathrm{Pc}_{2}(\mathrm{EP})_{4} / \mathrm{PSS}-\mathrm{Gr}$ composites enhanced the catalytic activity of oxygen reduction reaction. The $\pi$ electron conjugated structure of the $\mathrm{MN}_{4}$-type phthalocyanine macrocyclic system strongly influenced the one-step four-electron electrocatalytic process of the $\mathrm{M}_{2} \mathrm{Pc}_{2}(\mathrm{EP})_{4} / \mathrm{PSS}-\mathrm{Gr}$ composites. Moreover, the $\pi-\pi$ interactions between the $\mathrm{M}_{2} \mathrm{Pc}_{2}(\mathrm{EP})_{4}$ and PSS-Gr dramatically enhanced the $\pi$ electron density in the conjugated structure and oxygen could be reduced more easily. The electrocatalytic activity test was displayed in the order of $\mathrm{Fe}_{2} \mathrm{Pc}_{2}(\mathrm{FP})_{4} / \mathrm{PSS}-\mathrm{Gr}>$ $\mathrm{Co}_{2} \mathrm{Pc}_{2}(\mathrm{EP})_{4} / \mathrm{PSS}-\mathrm{Gr}>\mathrm{Zn}_{2} \mathrm{Pc}_{2}(\mathrm{EP})_{4} / \mathrm{PSS}-\mathrm{Gr}$. The results indicated that the catalytic performance of $\mathrm{M}_{2} \mathrm{Pc}_{2} \mathrm{R}_{\mathrm{n}}$ could be enhanced by the modification of $\pi$ electron conjugated structure of $\mathrm{M}_{2} \mathrm{Pc}_{2}(\mathrm{EP})_{4}$ and carbon materials.
\end{abstract}

Keywords: metallophthalocyanines; PSS-Graphene; $\pi-\pi$ interactions; ORR

\section{Introduction}

With the exhausting of traditional energy sources and increasing concerns of environmental pollution, it is urgent to explore and utilize clean energy. Fuel cells have become the research hotspots for new energy development because of their low cost, simple structure, special energy density and other merits [1-3]. Nevertheless, the high overpotentials for the oxygen reduction reactions create an extremely negative impact on the energy efficiency of air-based battery systems [4]. Although Pt and its alloys contribute significantly in decreasing the overpotential of oxygen reduction reaction (ORR) because of their high catalytic activity, they are limited in the scarcity of reserves, high price and lack of excellent methanol resistance [5]. To overcome this problem, extensive efforts have been implemented to study low-cost, non-precious metal substitute catalysts for Pt/C catalysts [6,7]. Specially, many reports have pointed out that the ability to carry oxygen molecules plays a key role in the ORR process $[8,9]$. Among the large variety of metal macrocycles, metal- $\mathrm{N}_{4}$-chelates, like metalloporphyrin 
(MPs) and metallophthalocyanine (MPcs), which have an $18 \pi$ electrons conjugated structure, have the biomimetic oxygen carrier functions similar to the naturally occurring hemeproteins [10]. Due to the delocalization effect and weakly bonding character of $\pi$ electron clouds in a conjugated structure, the metal- $\mathrm{N}_{4}$-chelates with $\pi$ electron conjugated structure could be oxidized and reduced much more easily, establishing them as a promising precursor for preparing ORR catalysts [11-13]. Compared with MPs, the periphery of the benzene ring of phthalocyanines can be modified with a variety of substituents, giving MPcs a variety of chemical structures and properties [14-16]. The chemical natures of the ligand and the central ion strongly influence the catalytic properties of the metal- $\mathrm{N}_{4}$-chelates macrocycles. In the ORR process, $\mathrm{O}_{2}$ is coordinated to the $\mathrm{M}$ of MPcs and the electrons then migrate from the MPcs to $\mathrm{O}_{2}$ to form adduct $\mathrm{MPc}_{-} \mathrm{O}_{2}{ }^{-}[17,18]$. Considering a high $\pi$ electron density of the conjugated structure, metallophthalocyanines have an excellent catalytic activity for oxygen reduction reaction [19-21].

In recent years, a new class of ball-type $\mathrm{M}_{2} \mathrm{Pc}_{2}$ compounds containing two metal centrals has drawn much attention because of its attractive structure [22,23]. Both the face-to-face monomer distance and the $\mathrm{d}$ filling of the metal central ions can significantly affect the ball-type Pcs' physical and chemical behavior [24,25]. For the $\mathrm{M}_{2} \mathrm{Pc}_{2}$ with a strong ligand-field effects of $\mathrm{MN}_{4}$-chelates, the catalytic activity is mainly affected by the chemical structure of the phthalocyanines, the radius and the d-filling of the metal central ions [26]. In addition, the presence of bridging units including electronegative groups highly enhanced catalytic activity of the phthalocyanines. The multiple electron-withdrawing substituents on the periphery of metal Pcs increased their catalytic activity [25]. The results pointed out that the possibility of the increase of the catalytic performance by the modification of the main $\mathrm{M}_{2} \mathrm{Pc}_{2}$ skeleton, and encouraged us to design phthalocyanine compound containing methoxy substituents. Furthermore, reports have also pointed out that MPc loaded on carbon materials is conducive to enhance the catalytic activity for the oxygen reduction reaction $[27,28]$. Graphene oxide has a high conductivity, excellent electron mobility and relatively high theoretical specific surface areas, establishing itself as a good candidate to provide a pathway for fast electron transferring and to prevent the aggregation of MPcs nanoparticles $[29,30]$. It has demonstrated that the catalytic activity of the $\pi$ electron conjugated structure towards oxygen reduction reaction are related to the strong $\pi-\pi$ supramolecular interaction between MPc compounds and graphene, which promote electron transfer between them leading to an apparent improvement for the oxidative reactions [31-34]. However, pristine GO possesses few proton-conducting groups, which negatively enhances the conductivity of GO. Therefore, grafting GO with a sulfonated group (-SO $\mathrm{SO}_{3} \mathrm{H}$; PSS-Gr) using various methods has been studied, as this strategy not only improved the conductivity of the GO, but also enabled the better dispersibility of GO [35].

Some studies have provided valuable mechanistic insights for the formation of $\mathrm{M}_{2} \mathrm{PcR}_{\mathrm{n}}-\mathrm{O}_{2}$ intermediates. However, the study on the effects of the $\pi$ electron conjugated structure and the $\pi-\pi$ interactions between the $\mathrm{M}_{2} \mathrm{Pc}_{2}(\mathrm{EP})_{4}$ and PSS-Gr generally restrict the design of the $\mathrm{M}_{2} \mathrm{Pc}_{2} \mathrm{R}_{\mathrm{n}}$-based catalysts. In this work, composites of binuclear ball-type metallophthalocyanines with methoxy substituents $\left(\mathrm{M}_{2} \mathrm{Pc}_{2}(\mathrm{EP})_{4}, \mathrm{M}=\mathrm{Fe}(\mathrm{II}), \mathrm{Co}(\mathrm{II})\right.$ and $\left.\mathrm{Zn}(\mathrm{II})\right)$ were loaded on the surface of PSS-Graphene (PSS-Gr), to enhance the catalytic activity and stability for ORR based on the $\pi$ electron conjugated structure of the $\mathrm{MN}_{4}$-type phthalocyanine macrocyclic system, and the $\pi-\pi$ supramolecular interaction between MPc nanoparticles and graphene.

\section{Experimental}

\subsection{Materials}

4, 4-bis (4-hydroxyphenyl) pentanoic acid (98\%) and 4-nitrophthalonitrile (99\%) were purchased from Aladdin (Shanghai, China). The other chemicals were of analytical grade and were used without further purification. The target $\mathrm{M}_{2} \mathrm{Pc}_{2}(\mathrm{EP})_{4}$ compounds were prepared by taking bisphthalonitrile and the corresponding metal salts $(\mathrm{M}=\mathrm{Fe}(\mathrm{II}), \mathrm{Co}(\mathrm{II})$, and $\mathrm{Zn}(\mathrm{II}))$ as the raw materials in the dimethylaminoethanol (DMAE). This was done according to the literature [25]. 
Preperation of $\mathrm{M}_{2}(\mathrm{II}) \mathrm{Pc}_{2}(\mathrm{EP})_{4}$ : Bisphthalonitrile (0.56 g, $\left.1.02 \mathrm{mmol}\right), \mathrm{Zn}(\mathrm{OAc})_{2} 2 \mathrm{H}_{2} \mathrm{O}(0.112 \mathrm{~g}$, $0.52 \mathrm{mmol}$ ) and $4 \mathrm{~mL}$ DMAE were poured into a Teflon-lined autoclave at $220^{\circ} \mathrm{C}$ for $4 \mathrm{~h}$ (Figure 1 ). The reaction mixture was then poured into methanol to produce a precipitate, and the precipitate was washed sequentially with acetic acid, water and methanol. The crude product was then dissolved in DMF and reprecipitated by gradually adding methanol to the solution. The precipitate was washed again as in the previous method followed by centrifugation and dried at $100{ }^{\circ} \mathrm{C}$ in an oven.

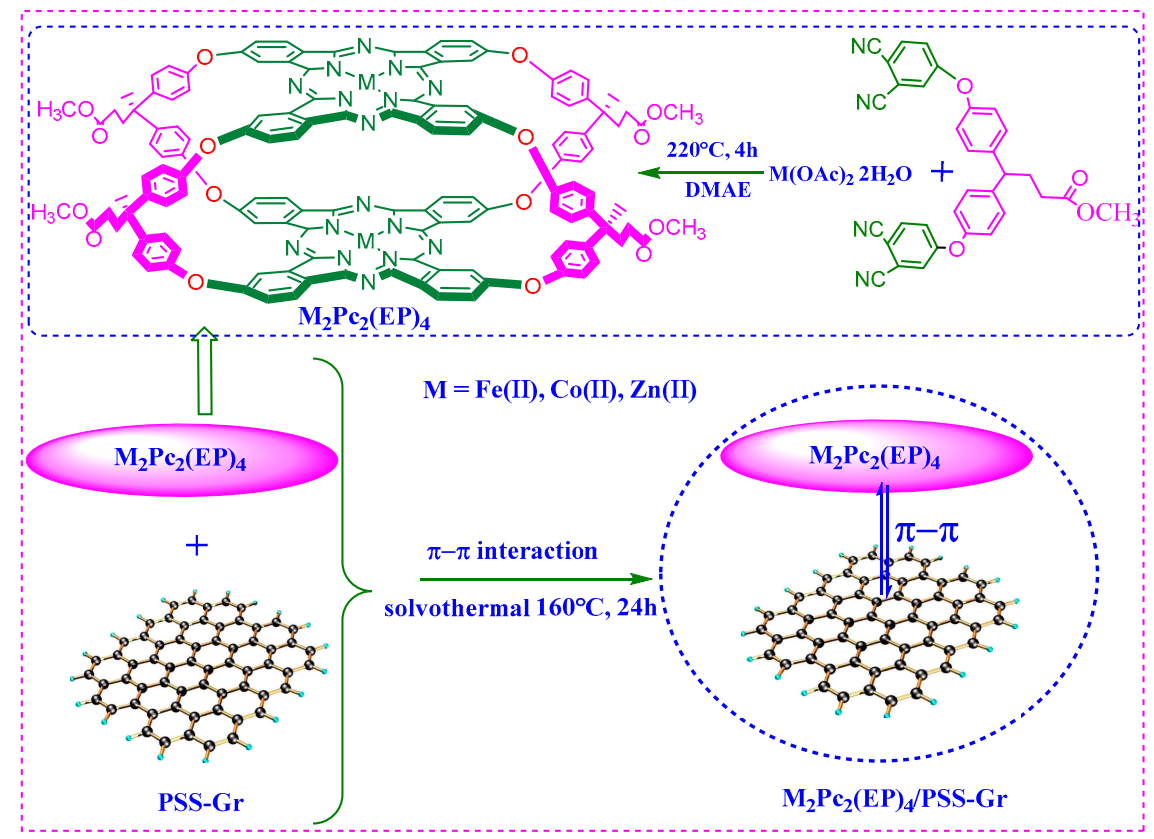

Figure 1. Schematic illustration of the preparation process for the $\mathrm{M}_{2} \mathrm{Pc}_{2}(\mathrm{EP})_{4} /$ polystyrene sodium sulfonate modified graphene (PSS-Gr) composites.

$\left[2^{\prime}, 10^{\prime}, 16^{\prime}, 24^{\prime}\right.$-\{Tetrakis-4,4'-bis (4- (3-cyano-4-isocyanophenoxy) phenyl) pentanoate diphthalocyaninato) dizinc (II)]: $\mathrm{Zn}_{2}(\mathrm{II}) \mathrm{Pc}_{2}(\mathrm{EP})_{4}(0.3815 \mathrm{~g}$, yield $64.21 \%)$, green solid, m.p. $>300{ }^{\circ} \mathrm{C}$. IR $(\mathrm{KBr}) v_{\max } / \mathrm{cm}^{-1}: 1715\left(v_{\mathrm{C}}=\right.$ o); $1381\left(v_{\mathrm{C}}=\mathrm{C}\right) ; 892\left(v_{\mathrm{M}-\mathrm{N}}\right) ; 2972,1009\left(v_{\mathrm{C}-\mathrm{H}(\mathrm{Pc})}\right), 1229\left(v_{\mathrm{Ar}-\mathrm{O}-\mathrm{Ar}}\right), 740\left(v_{\mathrm{Pc}}\right)$. UV-Vis (DMF) $\lambda_{\max } / \mathrm{nm}: \mathrm{B}$ band: 267, 354; $Q$ band: 612, 677. Anal. Cald. for $\mathrm{C}_{32} \mathrm{H}_{16} \mathrm{~N}_{8} \mathrm{Zn}$ : C, 69.78; H, 4.10; N, 9.58; Found: C, $69.21 ; \mathrm{H}, 4.54 ; \mathrm{N}, 9.29$.

$\left[2^{\prime}, 10^{\prime}, 16^{\prime}, 24^{\prime}-\{\right.$ Tetrakis-4, 4'-bis (4- (3-cyano-4-isocyanophenoxy) phenyl) pentanoate diphthalocyaninato) diiron (II)]: $\mathrm{Fe}_{2}(\mathrm{II}) \mathrm{Pc}_{2}(\mathrm{EP})_{4}(0.2120$ g, yield $36.64 \%)$, olive green solid, m.p. $>300{ }^{\circ} \mathrm{C}$. IR $(\mathrm{KBr}) v_{\max } / \mathrm{cm}^{-1}$ : $1713\left(v_{\mathrm{C}}=\mathrm{o}\right) ; 1401\left(v_{\mathrm{C}}=\mathrm{C}\right) ; 874\left(v_{\mathrm{M}-\mathrm{N}}\right) ; 2970,1011\left(v_{\mathrm{C}-\mathrm{H}(\mathrm{Pc})}\right), 1234\left(v_{\mathrm{Ar}-\mathrm{O}-\mathrm{Ar}}\right), 752\left(v_{\mathrm{Pc}}\right) . \mathrm{UV}-\mathrm{Vis}(\mathrm{DMF})$ $\lambda_{\max } / \mathrm{nm}$ : B band: 267, 323; $\mathrm{Q}$ band: 621, 668. Anal. Cald. for $\mathrm{C}_{32} \mathrm{H}_{16} \mathrm{~N}_{8} \mathrm{Fe}$ : C, 70.07; H, 4.12; N, 9.62; Found: C, 69.68; H, 3.63; N, 9.27.

$\left[2^{\prime}, 10^{\prime}, 16^{\prime}, 24^{\prime}-\{\right.$ Tetrakis-4, 4'-bis (4- (3-cyano-4-isocyanophenoxy) phenyl) pentanoate diphthalocyaninato) dicobalt (II]: $\mathrm{Co}_{2}(\mathrm{II}) \mathrm{Pc}_{2}(\mathrm{EP})_{4}(0.3021 \mathrm{~g}$, yield $51.52 \%)$, dark blue solid, m.p. $>300{ }^{\circ} \mathrm{C}$. IR $(\mathrm{KBr}) v_{\max } / \mathrm{cm}^{-1}$ : $1707\left(v_{\mathrm{C}}=\mathrm{o}\right) ; 1387\left(v_{\mathrm{C}}=\mathrm{C}\right) ; 891\left(v_{\mathrm{M}-\mathrm{N}}\right) ; 2970,1011\left(v_{\mathrm{C}-\mathrm{H}(\mathrm{Pc})}\right), 1231\left(v_{\mathrm{Ar}-\mathrm{O}-\mathrm{Ar}}\right), 745\left(v_{\mathrm{Pc}}\right) . \mathrm{UV}-\mathrm{Vis}(\mathrm{DMF})$ $\lambda_{\max } / \mathrm{nm}$ : B band: 268, 362; $\mathrm{Q}$ band: 668. Anal. Cald. for $\mathrm{C}_{32} \mathrm{H}_{16} \mathrm{~N}_{8} \mathrm{Co}$ : C, 69.97; H, 4.11; N, 9.61; Found: C, 69.55; H, 4.56; N, 9.19.

\subsection{Characterization}

Transmission electron microscopy (TEM) analysis was performed on a JEOL JEM-2010 electron microscope at $200 \mathrm{kV}$. The system consists of a vertical SEM column that was situated at $36^{\circ}$ relative to the FIB column, operating at $3 \mathrm{kV}$ to optimize surface sensitivity. The IR spectra were recorded on a Germany Bruker Vertex70 spectrometer (Bruker, Karlsruhe, Germany). The UV-vis absorbance was 
recorded on a UV/visible spectrophotometer (UV-1600, Shanghai, China) using a quartz cell with a path length of $10 \mathrm{~mm}$ at room temperature. X-ray photoelectron spectroscopy (XPS) was measured using an Axis Ultra spectrometer with an $\mathrm{Al}$ (Mono) $\mathrm{K} \alpha \mathrm{X}$-ray source $(1486.6 \mathrm{eV})$. The binding energies (BE) were normalized to the signal for adventitious carbon at $284.8 \mathrm{eV}$. The electrocatalytic performance was evaluated by an electrochemical workstation CHI 660E (Shanghai CHENHUA Company, Shanghai, China) and a Pine Instrument Company AF-MSRCE modulator rate rotator (Grove, PA, USA) in a 0.1 $\mathrm{M} \mathrm{KOH}$ solution, separately.

\subsection{Synthesis}

\subsubsection{Polystyrene Sodium Sulfonate Modified Graphene (PSS-Gr) Preparation}

Graphene oxide (GO), obtained from Aladain Co. Ltd. (Shanghai, China) was dispersed in $100 \mathrm{~mL}$ distilled water with an ultrasonic technique, followed by the addition of $1 \mathrm{~g}$ of sodium polystyrene sulfonate at room temperature, and stirred for $12 \mathrm{~h}$. Then, $2 \mathrm{~mL}$ of hydrazine hydrate was then added. The crude products were washed with deionized water, ethanol and n-pentanol, followed by centrifugation and then drying at $100^{\circ} \mathrm{C}$.

\subsubsection{Preparation of $\mathrm{Fe}_{2} \mathrm{Pc}_{2}(\mathrm{EP})_{4} / \mathrm{PSS}-\mathrm{Gr}$}

The $\mathrm{Fe}_{2} \mathrm{Pc}_{2}(\mathrm{EP})_{4} / \mathrm{PSS}-\mathrm{Gr}$ composites were synthesized by a facile "solvothermal $\pi-\pi$ assembly" method, using PSS-Gr and $\mathrm{Fe}_{2} \mathrm{Pc}_{2}(\mathrm{EP})_{4}$ as the precursors (Figure 1). In brief, $0.1503 \mathrm{~g}$ of PSS-Gr powder was dispersed in $10 \mathrm{~mL}$ of DMF solution with an ultrasonic technique for $10 \mathrm{~min}$, followed by the addition of $0.1100 \mathrm{~g}$ metallophthalocyanine $\mathrm{Fe}_{2} \mathrm{Pc}_{2}(\mathrm{EP})_{4}$. The resulting solution was ultrasonically dispersed for $2 \mathrm{~h}$. Nitrogen gas was then bubbled into the mixture to remove oxygen and was then poured into a Teflon-lined autoclave at $160^{\circ} \mathrm{C}$ for $24 \mathrm{~h}$. All of the crude products were washed with $\mathrm{DMF}$, deionized water, ethanol and n-pentanol, followed by centrifugation and drying at $100{ }^{\circ} \mathrm{C}$ in an oven.

The $\mathrm{Co}_{2} \mathrm{Pc}_{2}(\mathrm{EP})_{4}$ PSS-Gr and $\mathrm{Zn}_{2} \mathrm{Pc}_{2}(\mathrm{EP})_{4} / \mathrm{PSS}-\mathrm{Gr}$ composites were prepared under the same conditions.

\subsection{Evaluation of the Electrocatalytic Activity}

The electrocatalytic performance of $\mathrm{M}_{2} \mathrm{Pc}_{2}(\mathrm{EP})_{4} / \mathrm{PSS}-\mathrm{Gr}$ composites for the oxygen reduction reaction was measured by cyclic voltammetry $(\mathrm{CV})$ and rotating disk electrode (RDE) techniques in a $0.1 \mathrm{M} \mathrm{NaOH}$ solution at room temperature. Specifically, the modified glassy carbon electrode is used as a working electrode. The reference electrode is saturated calomel electrode (SCE) and the platinum (Pt) wire electrode is used as counter electrode, respectively. The cyclic voltammetry tests were investigated in an $\mathrm{O}_{2}$-saturated $0.1 \mathrm{M} \mathrm{NaOH}$ solution with the scan rate of $100 \mathrm{mV} \mathrm{s}^{-1}$. The rotating disk electrode (RDE) test was measured with a glassy carbon electrode ( $5 \mathrm{~mm}$ diameter) in $\mathrm{O}_{2}$-saturated $0.1 \mathrm{M} \mathrm{NaOH}$ solution under quasistationary conditions $\left(5 \mathrm{mV} \cdot \mathrm{s}^{-1}\right.$ sweep rate) at $25^{\circ} \mathrm{C}$. The rotating disk electrode (RDE) was performed on a CHI 660E electrochemical workstation with an AF-MSRCE modulator rate rotator (Pine Instrument Company) using a standard three-electrode system. A platinum ring electrode and glassy carbon disk (5.61 mm diameter) was selected as the working electrode. The collection efficiency of the platinum ring was $37 \%$.

\section{Results and Discussion}

\subsection{Morphology and Structure of $M_{2} P_{c_{2}}(E P)_{4} / P S S-G r$ Composites}

The surface morphology of the $\mathrm{M}_{2} \mathrm{Pc}_{2}(\mathrm{EP})_{4} / \mathrm{PSS}-\mathrm{Gr}$ composites was studied by SEM and TEM images. As illustrated in Figure 2, a wrinkled paper-like feature was observed for the PSS-Gr, indicating a typical feature of the graphene sheet. In contrast to the TEM micrograph of PSS-Gr that appears transparent (Figure $2 \mathrm{~b}$ ), numerous dark particles of $\mathrm{M}_{2} \mathrm{Pc}_{2}(\mathrm{EP})_{4}$, as indicated by the white arrow, were 
observed on the PSS-Gr layer from the TEM image of the $\mathrm{M}_{2} \mathrm{Pc}_{2}(\mathrm{EP})_{4} / \mathrm{PSS}-\mathrm{Gr}$ composites. It can be seen that $\mathrm{M}_{2} \mathrm{Pc}_{2}(\mathrm{EP})_{4}$ nanoparticles were dispersed uniformly on the PSS-Gr surface.
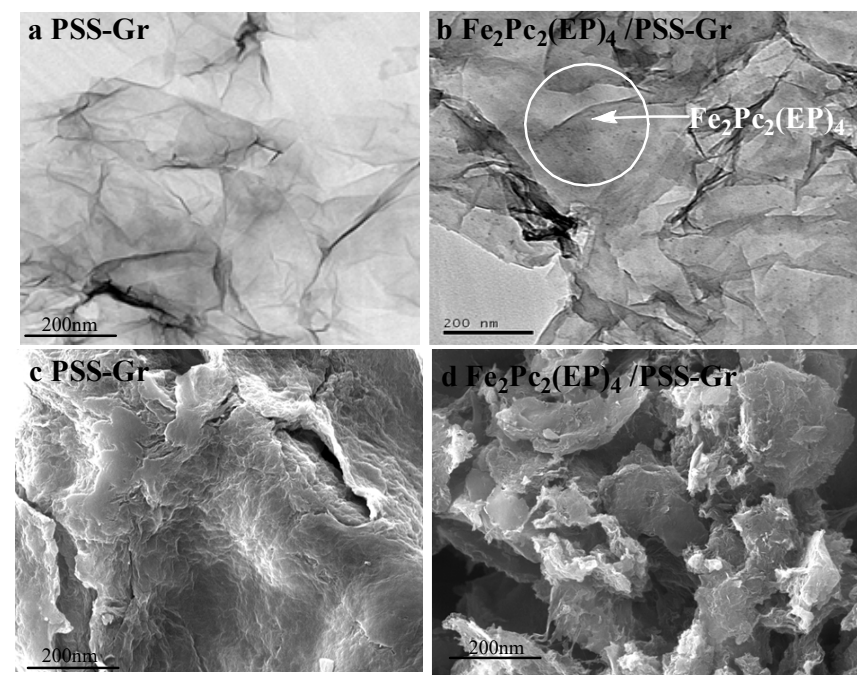

Figure 2. TEM and SEM images of PSS-Gr and $\mathrm{Fe}_{2} \mathrm{Pc}_{2}(\mathrm{EP})_{4} / \mathrm{PSS}-\mathrm{Gr} ;(\mathbf{a}),(\mathbf{c})$ TEM and SEM images of PSS-Gr; (b), (d) TEM and SEM images of $\mathrm{Fe}_{2} \mathrm{Pc}_{2}(\mathrm{EP})_{4} / \mathrm{PSS}-\mathrm{Gr}$.

The UV-Vis spectra of the $\mathrm{Fe}_{2} \mathrm{Pc}_{2}(\mathrm{EP})_{4} / \mathrm{PSS}-\mathrm{Gr}$ composites is shown in Figure 3. The "Q-band" of $\mathrm{Fe}_{2} \mathrm{Pc}_{2}(\mathrm{EP})_{4}$ appeared at around $668 \mathrm{~nm}$, because of the $\pi-\pi$ originating from the $\mathrm{HOMO}\left(\mathrm{a}_{1 \mathrm{u}}\right.$ and $\left.\mathrm{a}_{2 \mathrm{u}}\right)$ to the LUMO orbitals $\left(\mathrm{eg}_{\mathrm{g}}\right)$ [25]. The absorption at $621 \mathrm{~nm}$ is attributed to the dimmers of $\mathrm{Fe}_{2} \mathrm{Pc}_{2}(\mathrm{EP})_{4}$. The spectrum of the PSS-Gr did not exhibit any obvious absorption peaks from 300 to $900 \mathrm{~nm}$, while that of the $\mathrm{Fe}_{2} \mathrm{Pc}_{2}(\mathrm{EP})_{4} / \mathrm{PSS}-\mathrm{Gr}$ composites in DMF showed an absorption peak at $741 \mathrm{~nm}$. Compared with the $\mathrm{Fe}_{2} \mathrm{Pc}_{2}(\mathrm{EP})_{4}$, the absorption of the $\mathrm{Fe}_{2} \mathrm{Pc}_{2}(\mathrm{EP})_{4} / \mathrm{PSS}$-Gr samples are red shifted from $668 \mathrm{~nm}$ to $741 \mathrm{~nm}$, and the absorption of $\mathrm{Fe}_{2} \mathrm{Pc}_{2}(\mathrm{EP})_{4}$ dimmers at $621 \mathrm{~nm}$ disappeared. This suggests a strong $\pi-\pi$ supramolecular interaction between the $\mathrm{Fe}_{2} \mathrm{Pc}_{2}(\mathrm{EP})_{4}$ and PSS-GR [36-38], which will prevent the aggregation of $\mathrm{Fe}_{2} \mathrm{Pc}_{2}(\mathrm{EP})_{4}$ compounds and enhance the $\pi$ electron density in conjugated structure. Moreover, the strong $\pi-\pi$ supramolecular interaction facilitates electron transfer between them, leading to the observed improvement for the oxygen reduction reaction.
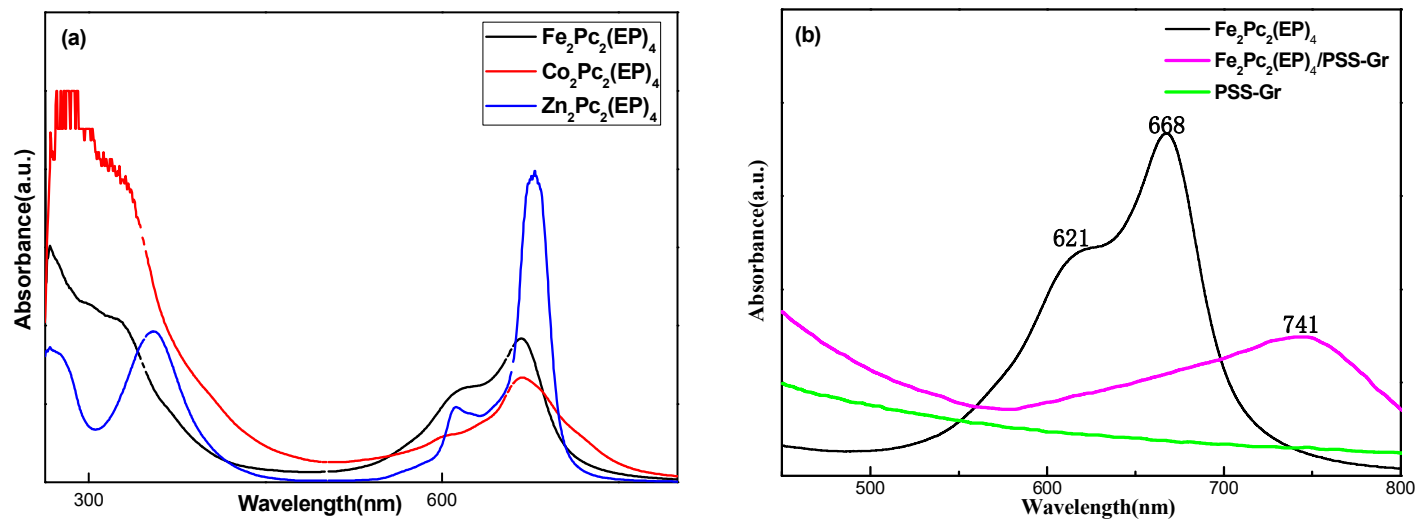

Figure 3. (a) UV-Vis spectra of $\mathrm{Fe}_{2} \mathrm{Pc}_{2}(\mathrm{EP})_{4}, \mathrm{Co}_{2} \mathrm{Pc}_{2}(\mathrm{EP})_{4}$, and $\mathrm{Zn}_{2} \mathrm{Pc}_{2}(\mathrm{EP})_{4}$, and (b) UV-vis spectra of $\mathrm{Fe}_{2} \mathrm{Pc}_{2}(\mathrm{EP})_{4} / \mathrm{PSS}-\mathrm{Gr}, \mathrm{Fe}_{2} \mathrm{Pc}_{2}(\mathrm{EP})_{4}$ and PSS-Gr.

To further illustrate the composition and chemical status of the as-prepared catalysts, the $\mathrm{Fe}_{2} \mathrm{Pc}_{2}(\mathrm{EP})_{4} / \mathrm{PSS}-\mathrm{Gr}$ were also analyzed by XPS. Figure 4a displays the XPS survey spectra of GO, PSS-Gr, $\mathrm{Fe}_{2} \mathrm{Pc}_{2}(\mathrm{EP})_{4}$, and $\mathrm{Fe}_{2} \mathrm{Pc}_{2}(\mathrm{EP})_{4} / \mathrm{PSS}-\mathrm{Gr}$ composites. The results showed that the $\mathrm{Fe}_{2} \mathrm{Pc}_{2}(\mathrm{EP})_{4} / \mathrm{PSS}-\mathrm{Gr}$ catalysts are composed of $\mathrm{O}, \mathrm{C}, \mathrm{N}$ and Fe elements, which further confirms the existence of $\mathrm{Fe}_{2} \mathrm{Pc}_{2}(\mathrm{EP})_{4}$ 
in the as-prepared samples. Compared with GO, the obviously decreasing O content for PSS-Gr indicates that a relatively high degree of reduction had been achieved during the hydrothermal process. The high-resolution N1s spectrum of the composite $\mathrm{Fe}_{2} \mathrm{Pc}_{2}(\mathrm{EP})_{4}$ and $\mathrm{Fe}_{2} \mathrm{Pc}_{2}(\mathrm{EP})_{4} / \mathrm{PSS}-\mathrm{Gr}$ are shown in Figure 4c,d. The two asymmetric broad peaks of $\mathrm{N} 1 \mathrm{~s}$ for $\mathrm{Fe}_{2} \mathrm{Pc}_{2}(\mathrm{EP})_{4}$ are located at $398.1 \mathrm{eV}$ and $399.4 \mathrm{eV}$, which correspond to the signals of $\mathrm{C}-\mathrm{N}$ and $\mathrm{C}=\mathrm{N}$ of pyrrolic ring in the phthalocyanine macrocycle, respectively $[39,40]$. What is more interesting is that the binding energy values of N1s in the $\mathrm{Fe}_{2} \mathrm{Pc}_{2}(\mathrm{EP})_{4} / \mathrm{PSS}-\mathrm{Gr}$ composites are obviously higher than those of pure $\mathrm{Fe}_{2} \mathrm{Pc}_{2}(\mathrm{EP})_{4}$, which confirms a strong interaction between $\mathrm{Fe}_{2} \mathrm{Pc}_{2}(\mathrm{EP})_{4}$ and PSS-Gr.
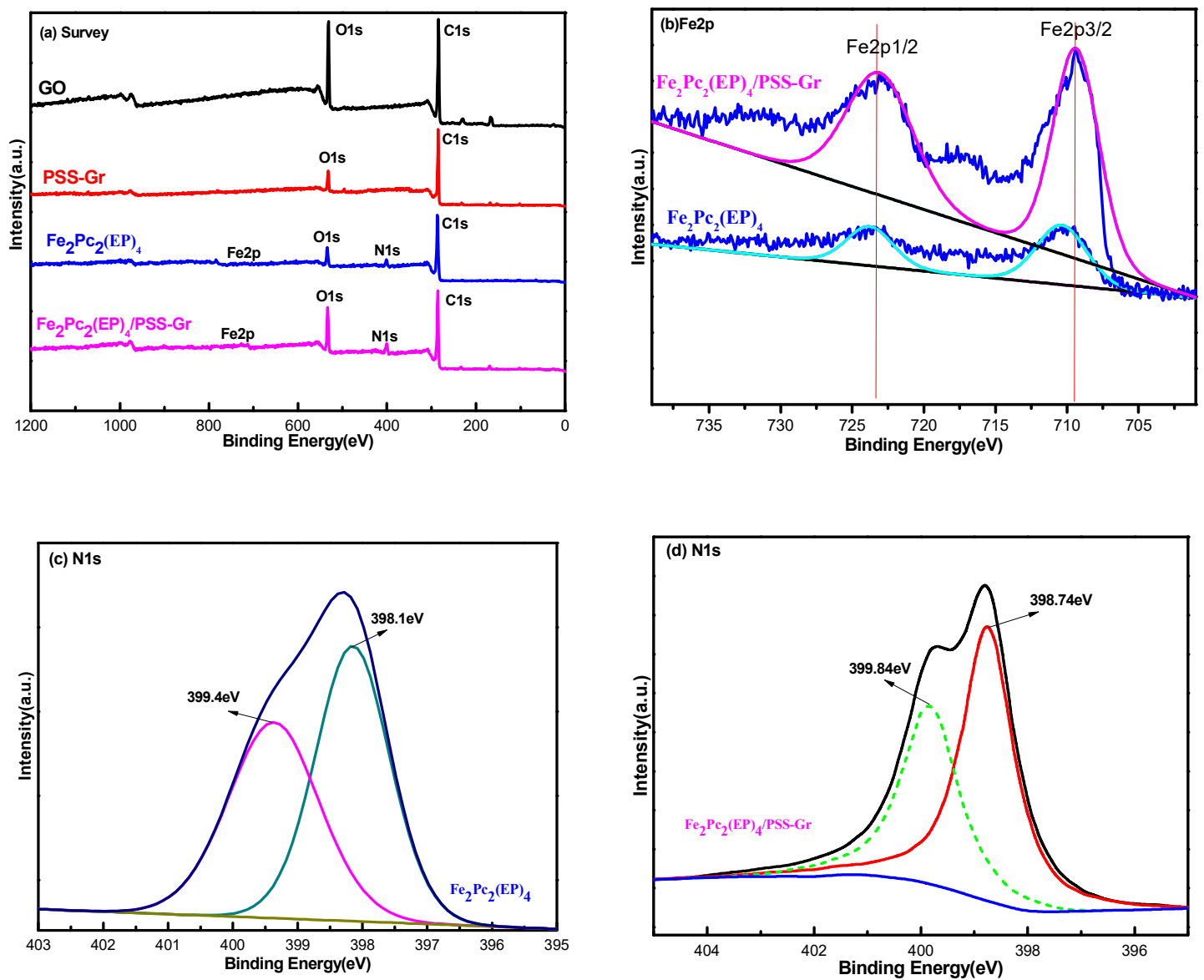

Figure 4. X-ray photoelectron spectroscopy (XPS) spectra of $\mathrm{Fe}_{2} \mathrm{Pc}_{2}(\mathrm{EP})_{4} / \mathrm{PSS}-\mathrm{Gr} ;(\mathbf{a}) \mathrm{XPS}$ survey spectra of GO, PSS-Gr, $\mathrm{Fe}_{2} \mathrm{Pc}_{2}(\mathrm{EP})_{4}$ and $\mathrm{Fe}_{2} \mathrm{Pc}_{2}(\mathrm{EP})_{4} / \mathrm{PSS}-\mathrm{GR}$; (b), (c), (d) High resolution of Fe2p, N1s XPS spectra of $\mathrm{Fe}_{2} \mathrm{Pc}_{2}(\mathrm{EP})_{4}$ and $\mathrm{Fe}_{2} \mathrm{Pc}_{2}(\mathrm{EP})_{4} / \mathrm{PSS}-\mathrm{Gr}$.

The high-resolution Fe2p spectrum of the catalysts is shown in Figure $4 \mathrm{~b}$. The peaks of Fe2p for $\mathrm{Fe}_{2} \mathrm{Pc}_{2}(\mathrm{EP})_{4}$ are located at $723.9 \mathrm{eV}$ and $710.6 \mathrm{eV}$, which correspond to the signals of $\mathrm{Fe} 2 \mathrm{p}_{1 / 2}$ and $\mathrm{Fe} 2 \mathrm{p}_{3 / 2}$ in the bivalent oxidation state, respectively. However, the binding energy values of Fe2p in the composites of $\mathrm{Fe}_{2} \mathrm{Pc}_{2}(\mathrm{EP})_{4} / \mathrm{PSS}-\mathrm{Gr}$ are obviously lower than those of pure $\mathrm{Fe}_{2} \mathrm{Pc}_{2}(\mathrm{EP})_{4}$ [19]. The shift again confirms a $\pi-\pi$ supramolecular interaction between $\mathrm{Fe}_{2} \mathrm{Pc}_{2}(\mathrm{EP})_{4}$ and PSS-Gr, indicating the as-prepared composites of $\mathrm{Fe}_{2} \mathrm{Pc}_{2}(\mathrm{EP})_{4}$ and PSS-Gr tend to form a hetero structure, rather than a physical mixture.

\subsection{Effects of $\pi$ Electron Conjugated Structure for ORR}

The electrocatalytic activity of the $\mathrm{M}_{2} \mathrm{Pc}_{2}(\mathrm{EP})_{4} / \mathrm{PSS}-\mathrm{Gr}$ composites for ORR were first tested by the technique of CV. As shown in Figure 5, the ORR peak currents in the voltammograms showed that $\mathrm{M}_{2} \mathrm{Pc}_{2}(\mathrm{EP})_{4} / \mathrm{PSS}-\mathrm{Gr}$ composites interact well with $\mathrm{O}_{2}$ through the redox-active character of the 
$\mathrm{M}^{2+}$ cores. The $\pi$ electron conjugated structure of the $\mathrm{MN}_{4}$-type phthalocyanine macrocyclic system strongly influences the redox-active character of the $\mathrm{M}^{2+}$ cores. Therefore, because of the $\mathrm{d}$ filling $\mathrm{t}_{2 \mathrm{~g}}{ }^{6}$ $\mathrm{e}_{\mathrm{g}}{ }^{0}$ of $\mathrm{Fe}(\mathrm{II})$ with a fully filled $\mathrm{t}_{2 \mathrm{~g}}$ and unoccupied $\mathrm{e}_{\mathrm{g}}$ orbitals, the central metal $\mathrm{Fe}$ (II) was favored to coordinate with dioxygen, and was oxidized to $\mathrm{Fe}(\mathrm{III})$ much more easily in the redox process [17]. The results showed that the $\mathrm{Fe}(\mathrm{II}) / \mathrm{Fe}(\mathrm{III})$ reduction peak current of $\mathrm{O}_{2}$ commenced at lower positive potentials $(-0.15 \mathrm{~V}$ vs. SCE) than that of the $\mathrm{Pt} / \mathrm{C}(-0.17 \mathrm{~V}$ vs. SCE). When the $\mathrm{Fe}(\mathrm{II}) / \mathrm{Fe}(\mathrm{III})$ redox transition occurs at low positive potentials, highly acidic Fe(III) species well interact well with dioxygen and provide a relatively low overpotential for ORR. Moreover, the reduction potential of $\mathrm{Fe}(\mathrm{III}) / \mathrm{Fe}(\mathrm{II})$ $(-0.15 \mathrm{~V}$ vs. SCE) is more positive than that of $\mathrm{Co}(\mathrm{III}) / \mathrm{Co}(\mathrm{II})(-0.21 \mathrm{~V}$ vs. SCE) and $\mathrm{Zn}(\mathrm{III}) / \mathrm{Zn}(\mathrm{II})(-0.59 \mathrm{~V}$ vs. SCE). The results indicated that the electrocatalytic activity is closely related to their radius and $\mathrm{d}$ filling of the active center ions. $\mathrm{Zn}_{2} \mathrm{Pc}_{2}(\mathrm{EP})_{4} / \mathrm{PSS}-\mathrm{Gr}$ shows a relatively low catalytic activity for ORR because of the fully filled $\mathrm{t}_{2 \mathrm{~g}}{ }^{6}$ and $\mathrm{e}_{\mathrm{g}}{ }^{4}$ orbitals, which make $\mathrm{Zn}$ (II) difficult to be oxidized to $\mathrm{Zn}$ (III) by the $\mathrm{O}_{2}$ in the vertical direction of the conjugate plane in a strong ligand-field. Whereas the ORR process occurs only on the phthalocyanine ring, and is independent of the central metal $\mathrm{Zn}$ (II).
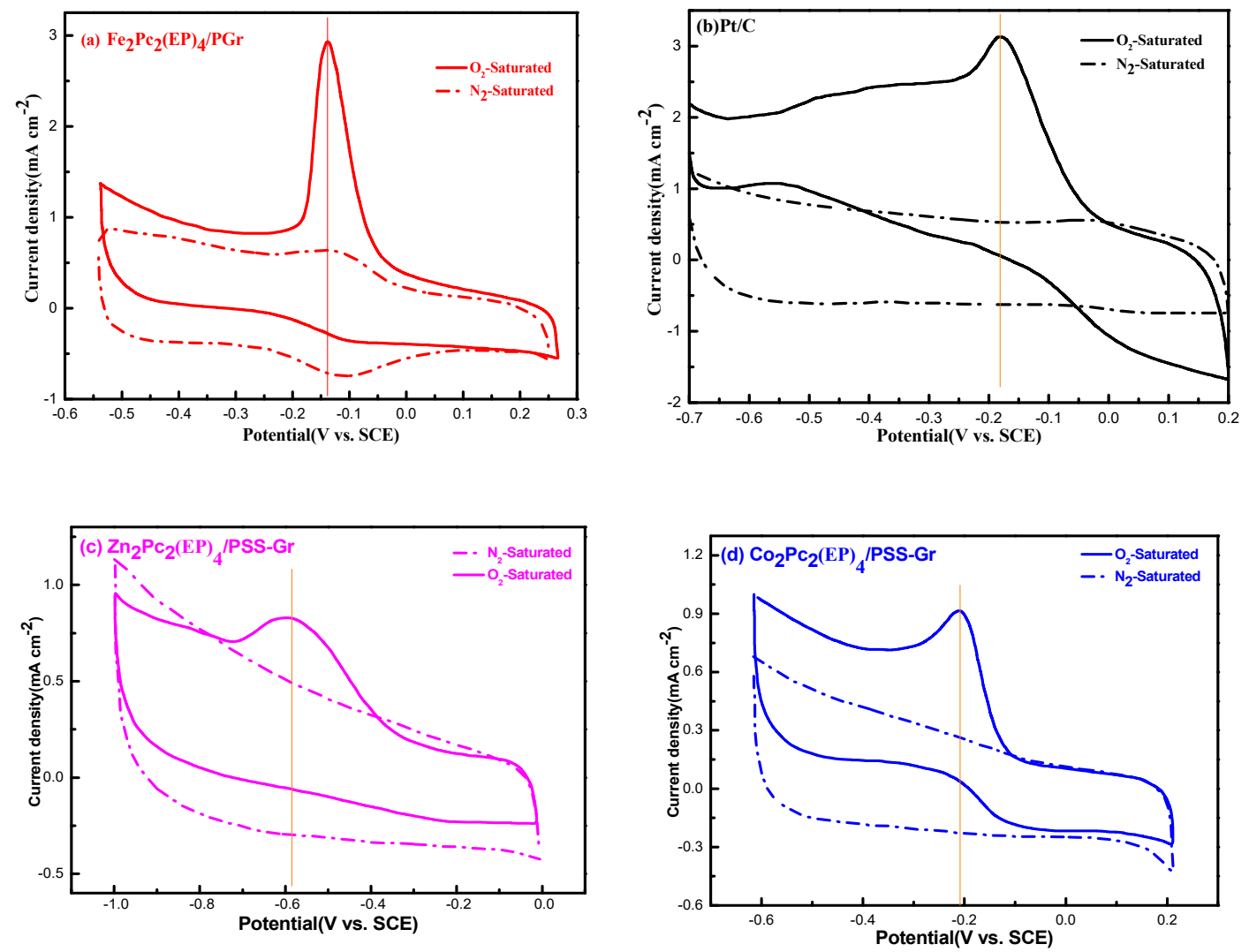

Figure 5. Cyclic Voltammograms curve of $\mathrm{M}_{2} \mathrm{Pc}_{2}(\mathrm{EP})_{4} / \mathrm{PSS}-\mathrm{Gr}$ and $\mathrm{Pt} / \mathrm{C}$ catalysts on glassy carbon electrodes; (a), (b), (c), (d) CV curve of $\mathrm{Fe}_{2} \mathrm{Pc}_{2}(\mathrm{EP})_{4} / \mathrm{PSS}-\mathrm{Gr}, \mathrm{Pt} / \mathrm{C}, \mathrm{Zn}_{2} \mathrm{Pc}_{2}(\mathrm{EP})_{4} / \mathrm{PSS}-\mathrm{Gr}$, and $\mathrm{Fe}_{2} \mathrm{Pc}_{2}(\mathrm{EP})_{4} / \mathrm{PSS}-\mathrm{Gr}$;

In order to further investigate the influence of the catalysts structures for ORR, the linear sweep voltammetry (LSV) measurement was performed on a rotating disk electrode (RDE) at a scanning rate of $5 \mathrm{mV}^{-1}$ in $\mathrm{O}_{2}$-saturated $0.1 \mathrm{M} \mathrm{KOH}$ solution with the rotational speed from $400 \mathrm{rpm}$ to 2500 $\mathrm{rpm}$. A comparison of the LSV results was recorded at $1600 \mathrm{rpm}$ rotational speed using $\mathrm{Pt} / \mathrm{C}, \mathrm{PSS}-\mathrm{Gr}$, $\mathrm{Fe}_{2} \mathrm{Pc}_{2}(\mathrm{EP})_{4}$ and $\mathrm{Fe}_{2} \mathrm{Pc}_{2}(\mathrm{EP})_{4} / \mathrm{PSS}-\mathrm{Gr}$ modified electrodes individually. The onset potential $\left(\mathrm{E}_{0}\right)$ and the limiting diffusion current density $\left(\mathrm{J}_{1}\right)$ were taken as measures of the catalytic activity. Compared with the ORR potentials of PSS-Gr $\left(-0.17 \mathrm{~V}\right.$ vs. SCE) and $\mathrm{Fe}_{2} \mathrm{Pc}_{2}(\mathrm{EP})_{4}(-0.27 \mathrm{~V}$ vs. SCE), the onset potential of $\mathrm{Fe}_{2} \mathrm{Pc}_{2}(\mathrm{EP})_{4} / \mathrm{Gr}$ was positively shifted to $-0.09 \mathrm{~V}$, which is close to the onset potential of $\mathrm{Pt} / \mathrm{C}(-0.07$ 
$\mathrm{V})$. The results indicated that the electrocatalytic activity of $\mathrm{Fe}_{2} \mathrm{Pc}_{2}(\mathrm{EP})_{4 /} \mathrm{PSS}-\mathrm{Gr}$ was enhanced by the $\pi-\pi$ supramolecular interaction between $\mathrm{Fe}_{2} \mathrm{Pc}_{2}(\mathrm{EP})_{4}$ compounds and PSS-Gr, which enhance the $\pi$ electron density in $\mathrm{Pc}_{2}(\mathrm{EP})_{4}$ conjugated structure, leading to an observed improvement for the oxygen reduction reaction $[41,42]$.

Furthermore, it is well known that a one-step four-electron process has more excellent electrocatalytic performances than the two-electron process for an oxygen reduction reaction [43-45]. The total electron transfer number $(n)$ in the ORR reaction is calculated by the Koutecky-Levich (K-L) equation given below (1) and (2):

$$
\begin{gathered}
\frac{1}{J}=\frac{1}{J K}+\frac{1}{J L}=\frac{1}{n F K C_{o}}+\frac{1}{B \omega^{1 / 2}} \\
B=0.62 n F C_{o}\left(D_{0}\right)^{2 / 3} v^{-1 / 6}
\end{gathered}
$$

where $\mathrm{J}\left(\mathrm{mA} / \mathrm{cm}^{2}\right)$ is the measured current density; $\mathrm{J}_{\mathrm{K}}$ and $\mathrm{J}_{\mathrm{L}}\left(\mathrm{mA} / \mathrm{cm}^{2}\right)$ are the kinetic and diffusion-controlled current density, respectively; $\omega$ is the angular velocity of the rotating disk $(\omega=2 \pi \mathrm{N}, \mathrm{N}$ is the linear rotation speed in $\mathrm{rpm}$ ); $\mathrm{n}$ is the total number of electron transferred per oxygen molecule in the ORR reaction; $F$ is the Faraday constant; $C_{0}$ is the bulk oxygen concentration; $\mathrm{D}_{0}$ is the diffusion coefficient of oxygen; and $v$ is the kinematic viscosity of the electrolyte.

The K-L points $\left(\mathrm{J}^{-1}\right.$ vs. $\left.\omega^{-1 / 2}\right)$ of $\mathrm{M}_{2} \mathrm{Pc}_{2}(\mathrm{EP})_{4} / \mathrm{PSS}-\mathrm{Gr}$ at different voltages an exhibited excellent linearity and the slope is consistent (Figure 6). The linearity of the K-L plots and the near parallelism of the fitting lines suggested first-order reaction kinetics for ORR. The electron transfer number $\mathrm{n}$ is further calculated by the Koutecky-Levich (K-L) equation. The $n$ for $\mathrm{Fe}_{2} \mathrm{Pc}_{2}(\mathrm{EP})_{4} / \mathrm{PSS}-\mathrm{Gr}$ was 3.89 at the voltage range from $-0.4 \mathrm{~V}$ to $-0.7 \mathrm{~V}$, and was similar in the redox process at different potentials. The results indicated that the ORR mainly proceeded a one-step four electron process for $\mathrm{Fe}_{2} \mathrm{Pc}_{2}(\mathrm{EP})_{4} / \mathrm{PSS}-\mathrm{Gr}$ which is similar to the $\mathrm{Pt} / \mathrm{C}$ catalysts.
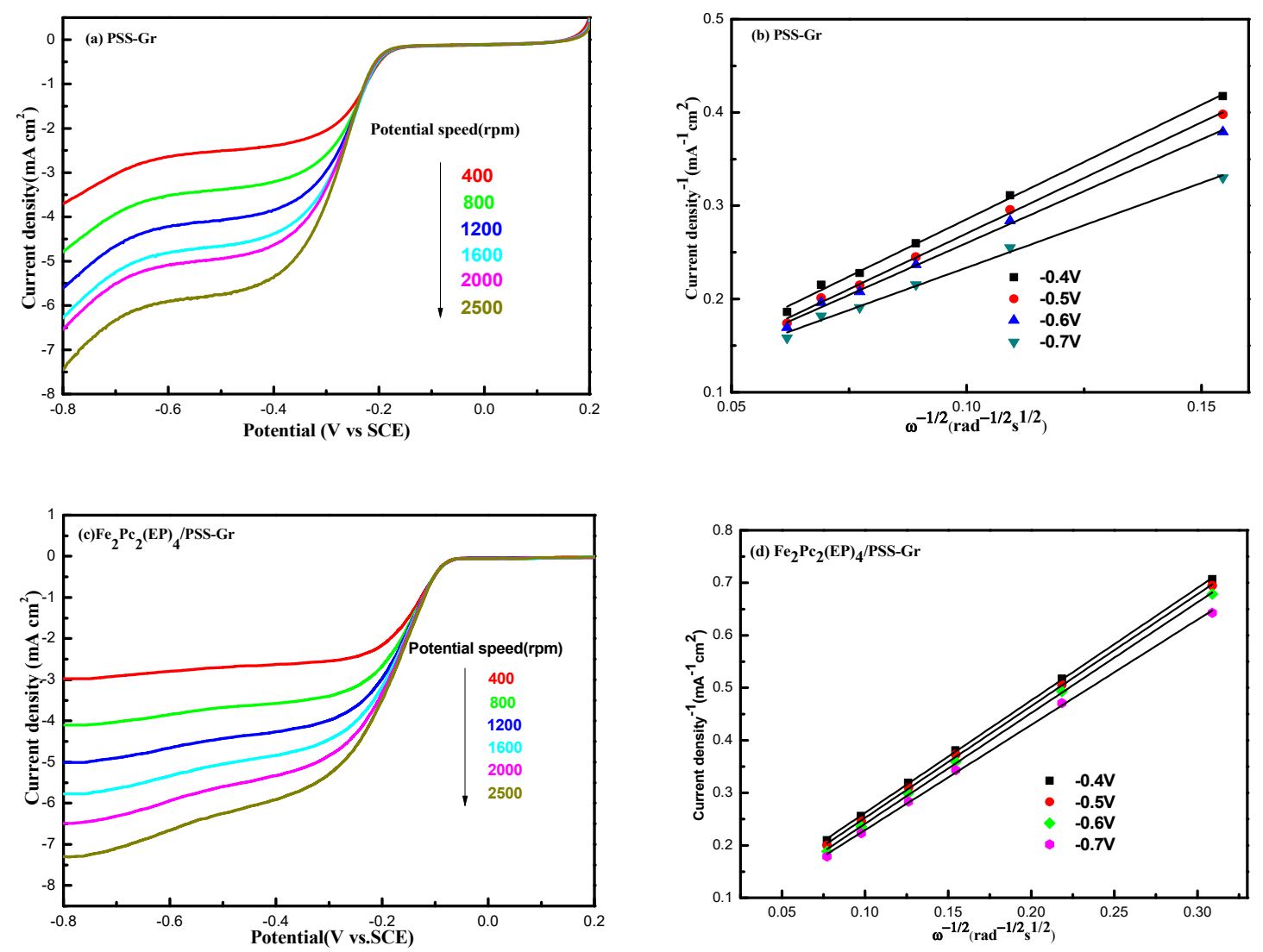

Figure 6. Cont. 

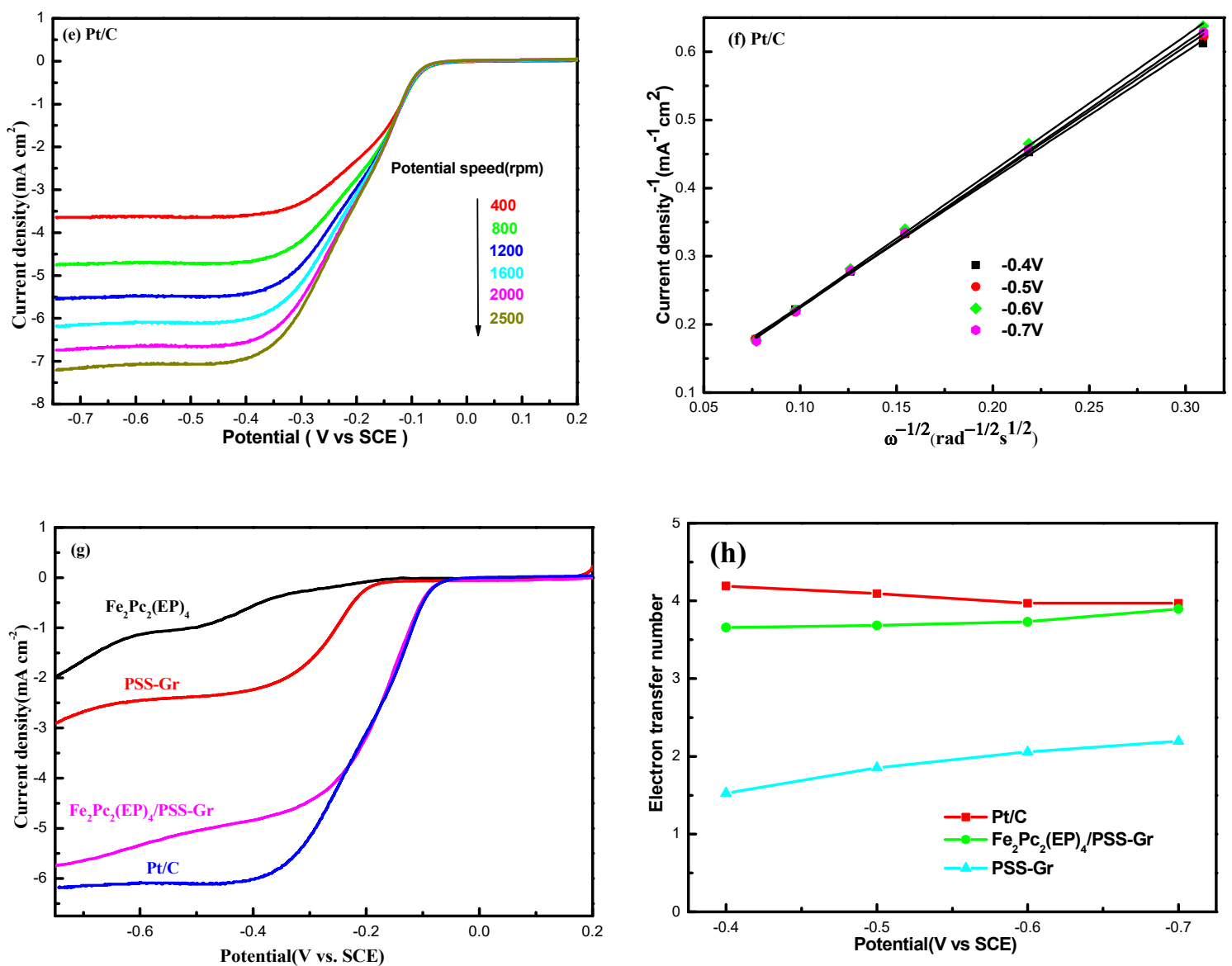

Figure 6. Electrocatalytic activities of $\mathrm{Pt} / \mathrm{C}$ and $\mathrm{Fe}_{2} \mathrm{Pc}_{2}(\mathrm{EP})_{4} / \mathrm{PSS}-\mathrm{Gr}$ at different rotation speed in $\mathrm{O}_{2}$-saturated 0.1 M KOH; (a), (c), (e), (g) the linear sweep voltammetry (LSV) curve; (b), (d), (f) Koutecky-Levich (K-L) plots; (h) the number of electrons transferred.

The cyclic voltammetry curves of $\mathrm{Pt} / \mathrm{C}$ and $\mathrm{Fe}_{2} \mathrm{Pc}_{2}(\mathrm{EP})_{4} / \mathrm{PSS}-\mathrm{Gr}$ were further investigated, revealing reveal the cross-effect in an $\mathrm{O}_{2}$ saturated $0.1 \mathrm{M} \mathrm{NaOH}$ solution containing $3 \mathrm{M} \mathrm{CH}_{3} \mathrm{OH}$. As shown in Figure 7 , the oxygen reduction peak of $\mathrm{Pt} / \mathrm{C}$ catalyst at $-0.20 \mathrm{~V}$ decreased significantly for the oxygen reduction reaction after adding methanol into the system, and a methanol oxidation peak appeared at $0.0 \mathrm{~V}$. However, the peak current density and peak potential had no significant difference for the $\mathrm{Fe}_{2} \mathrm{Pc}_{2}(\mathrm{EP})_{4} / \mathrm{PSS}-\mathrm{Gr}$ catalyst under the same conditions. The results indicate that the $\mathrm{Fe}_{2} \mathrm{Pc}_{2}(\mathrm{EP})_{4} / \mathrm{Gr}$ catalyst had a good methanol-tolerant performance in an alkaline medium in the presence of methanol.
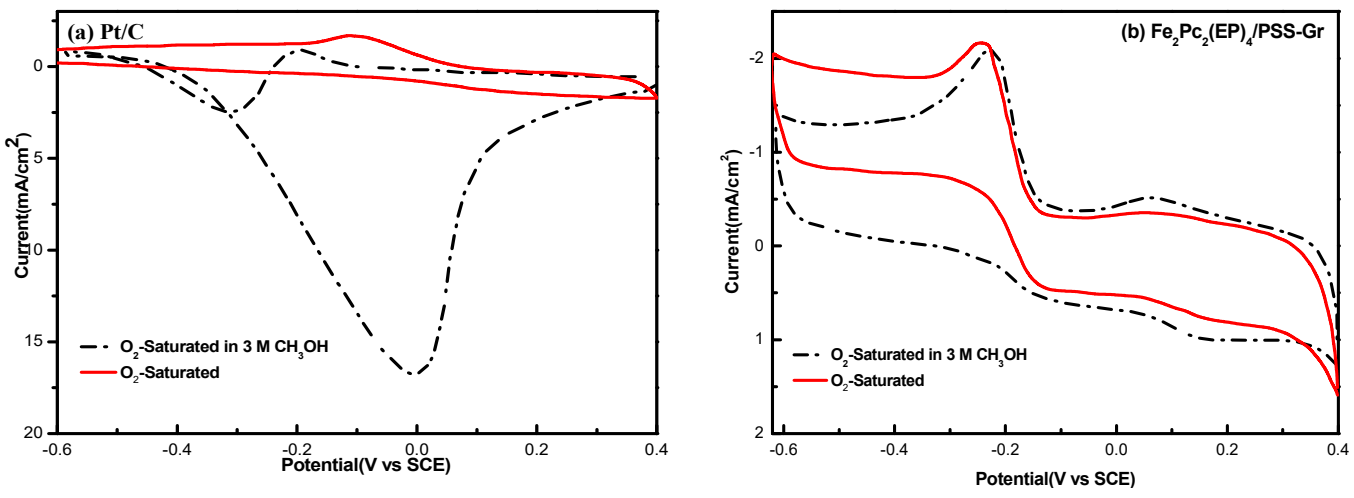

Figure 7. Cyclic voltammetry $(\mathrm{CV})$ curves of $\mathrm{Fe}_{2} \mathrm{Pc}_{2}(\mathrm{EP})_{4} / \mathrm{PSS}-\mathrm{Gr}$ in $\mathrm{O}_{2}$-saturated in a $0.1 \mathrm{M} \mathrm{KOH}$ solution and $\mathrm{O}_{2}$-saturated $0.1 \mathrm{M} \mathrm{KOH}$ solution with $3 \mathrm{M}$ methanol. (a) $\mathrm{Pt} / \mathrm{C}$, and (b) $\mathrm{Fe}_{2} \mathrm{Pc}_{2}(\mathrm{EP})_{4} / \mathrm{Gr}$. 
A mechanism was proposed for ORR catalyzed by $\mathrm{Fe}_{2} \mathrm{Pc}_{2}(\mathrm{EP})_{4} / \mathrm{PSS}-\mathrm{Gr}$ based on the experiment results and references (Figure 8 ). The electron transfer number $n$ for $\mathrm{Fe}(\mathrm{II})_{2} \mathrm{Pc}_{2}(\mathrm{EP})_{4} / \mathrm{PSS}-\mathrm{Gr}$ was 3.89 which was calculated by the Koutecky-Levich (K-L) equation. The results indicated that ORR mainly underwent a direct four electron pathway to result in $\mathrm{OH}^{-}$production. First, the $\mathrm{O}_{2}$ molecule was bonded to the central metal ion Fe(II) (d-filling of $\mathrm{t}_{2 \mathrm{~g}}{ }^{6} \mathrm{e}_{\mathrm{g}}{ }^{0}$ ) of the $\mathrm{MN}_{4}$-type $\mathrm{Fe}(\mathrm{II})_{2} \mathrm{Pc}_{2}(\mathrm{EP})_{4}$ macrocyclic system by bridge adsorption [16,17]. Bridge adsorption can coordinate one oxygen molecule with two central metal ions Fe(II), so it can form more stable peroxide intermediates, which are more conducive to oxygen-oxygen bond $(\mathrm{O}-\mathrm{O})$ breaking $[25,46,47]$. The electrons on the $\pi$ electron conjugated structure $\mathrm{Pc}_{2}(\mathrm{EP})_{4}$ migrate to the central metal ion $\mathrm{Fe}(\mathrm{II})$ and then to the $\mathrm{O}_{2}$ molecule, to form an adduct $\mathrm{Fe}(\mathrm{III})_{2} \mathrm{Pc}_{2}(\mathrm{EP})_{4} \cdot \mathrm{O}_{2}{ }^{-}$, which showed the structure of $\mathrm{Fe}(\mathrm{III})-\mathrm{O}-\mathrm{O}-\mathrm{Fe}(\mathrm{III})$ peroxo-species. The breaking of the $\mathrm{O}-\mathrm{O}$ linkage for $\mathrm{Fe}(\mathrm{III})-\mathrm{O}-\mathrm{O}-\mathrm{Fe}(\mathrm{III})$ peroxo species is expected to facilitate in the formation of $\mathrm{OH}^{-}$ions. The electrons on PSS-Gr then migrated to $\mathrm{Fe}(\mathrm{III})_{2} \mathrm{Pc}_{2}(\mathrm{EP})_{4}$ and $\mathrm{Fe}(\mathrm{III})_{2} \mathrm{Pc}_{2}(\mathrm{EP})_{4}$ was reduced to $\mathrm{Fe}(\mathrm{II})_{2} \mathrm{Pc}_{2}(\mathrm{EP})_{4}[19,32,33]$. Therefore, the $\pi$ electron conjugated structure of the $\mathrm{MN}_{4}$-type phthalocyanine macrocyclic system strongly influenced the one-step four-electron electrocatalytic process for ORR, and it effectively reduced the overpotential of the oxide reduction reaction [25]. Moreover, the performance of $\mathrm{M}_{2} \mathrm{Pc}_{2}(\mathrm{EP})_{4}$ catalysts was lower than that of the metallophthalocyanines with trifluoro methyl linkages [25]. The linkage of highly electrophilic groups, like trifluoro methyl groups, to the macrocycles dramatically enhanced the electrocatalytic performance. The comparison of the performances of $\mathrm{M}_{2} \mathrm{Pc}_{2}(\mathrm{EP})_{4}$ catalysts used in this work and in the reported article also points out the importance of the bridging units in the ball-type structure. More significantly, PSS-Gr dramatically enhanced the electrocatalytic activity of $\mathrm{M}_{2} \mathrm{Pc}_{2}(\mathrm{EP})_{4}$. PSS-Gr provide pathway for fast electron transferring and to prevent the aggregation of $\mathrm{M}_{2} \mathrm{Pc}_{2}(\mathrm{EP})_{4}$ catalysts. $\mathrm{M}_{2} \mathrm{Pc}_{2}(\mathrm{EP})_{4}$ were loaded on the surface of PSS-Gr to enhance the catalytic activity and stability for the ORR, based on the $\pi-\pi$ supramolecular interaction between MPcs molecules and graphene. The results indicated that PSS-Gr enhanced the catalytic activity and stability of $\mathrm{M}_{2} \mathrm{Pc}_{2}(\mathrm{EP})_{4}$ for the ORR based on the $\pi-\pi$ supramolecular interaction.

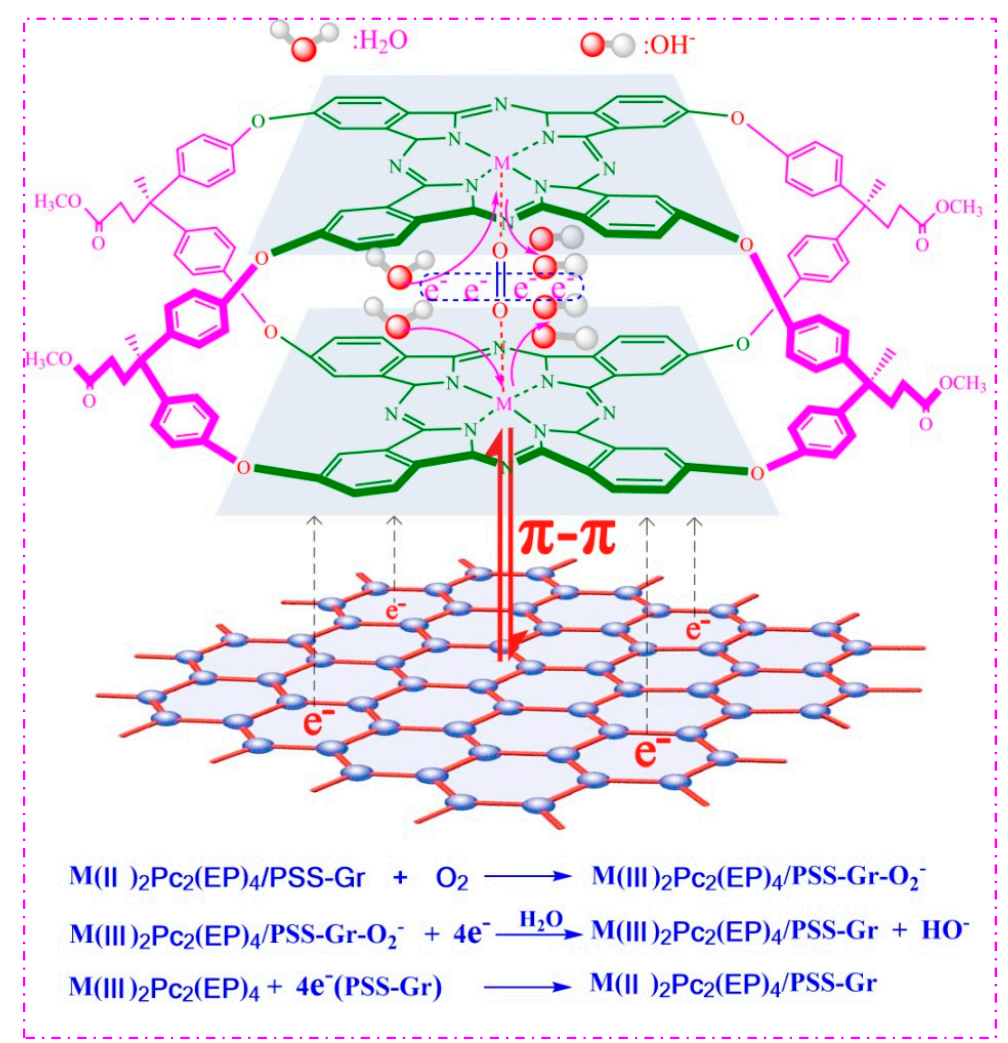

Figure 8. Mechanism for the oxygen reduction reaction (ORR) catalyzed by $\mathrm{Fe}_{2} \mathrm{Pc}_{2}(\mathrm{EP})_{4} / \mathrm{PSS}-\mathrm{Gr}$. 


\section{Conclusions}

Composites of PSS-graphene-wrapped binuclear ball-type metallophthalocyanines with methoxy substituents $\left(\mathrm{M}_{2} \mathrm{Pc}_{2}(\mathrm{EP})_{4}, \mathrm{M}=\mathrm{Fe}(\mathrm{II}), \mathrm{Co}(\mathrm{II})\right.$ and $\left.\mathrm{Zn}(\mathrm{II})\right)$ were synthesized to enhanced the electrocatalytic activity for the oxygen reduction reaction of $\mathrm{M}_{2} \mathrm{Pc}_{2}(\mathrm{EP})_{4}$. Compared to the commercial Pt/C catalysts, the $\mathrm{M}_{2} \mathrm{Pc}_{2}(\mathrm{EP})_{4} / \mathrm{PSS}-\mathrm{Gr}$ composites had a high electrocatalytic activity. The $\pi$ electron conjugated structure of the $\mathrm{MN}_{4}$-type phthalocyanine macrocyclic system strongly influenced the four-electron electrocatalytic process. PSS-Gr enhance the catalytic activity and stability of the $\mathrm{M}_{2} \mathrm{Pc}_{2}(\mathrm{EP})_{4}$ composites, based on the $\pi-\pi$ supramolecular interaction between MPcs molecules and graphene. PSS-Gr provide a pathway for fast electron transferring and prevent the aggregation of $\mathrm{M}_{2} \mathrm{Pc}_{2}(\mathrm{EP})_{4}$ catalysts. The results indicated that the catalytic performance of $\mathrm{M}_{2} \mathrm{Pc}_{2} \mathrm{R}_{n}$ could be enhanced by the modification of the $\pi$ electron conjugated structure of $\mathrm{M}_{2} \mathrm{Pc}_{2}(\mathrm{EP})_{4}$ and carbon materials.

Author Contributions: Conceptualization, G.Z., and L.B.; validation, G.Z., L.B.L., and Y.Z.; formal analysis, G.Z.; data curation, W.Z.; writing-original draft preparation, B.L.; writing-review and editing, G.Z., and W.Z.; visualization, T.L.; supervision, W.C.; project administration, G.Z.; funding acquisition, G.Z., W.Z. All authors have read and agreed to the published version of the manuscript.

Funding: This research received no external funding.

Acknowledgments: This research was supported by the Natural Science Foundation of Shaanxi Province (No. 2019JM-527), the National Natural Science Foundation of China (61604120, 21501139).

Conflicts of Interest: The authors declare no conflict of interest.

\section{References}

1. Guo, Y.; Jiang, Z.Q.; Wang, X.B.; Ying, W.; Chen, D.; Liu, S.H. Zwitterion threaded metal-organic framework membranes for direct methanol fuel cells. J. Mater. Chem. A 2018, 6, 19547-19554. [CrossRef]

2. Gago, A.S.; Acosta, D.M.; Arriaga, L.G.; Vante, N.A. Carbon supported ruthenium chalcogenide as cathode catalyst in a microfluidic formic acid fuel cell. J. Power. Sources 2011, 196, 1324-1328. [CrossRef]

3. Gong, L.Y.; Yang, Z.Y.; Li, K.; Xing, W.; Liu, C.P.; Ge, J.J. Recent development of methanol electrooxidation catalysts for direct methanol fuel cell. J. Energy. Chem. 2018, 27, 1618-1628. [CrossRef]

4. Ge, X.; Liu, Y.; Goh, F.T.; Hor, T.A.; Zong, Y.; Xiao, P. Dual-phase spinel $\mathrm{MnCo}_{2} \mathrm{O}_{4}$ and spinel $\mathrm{MnCo}_{2} \mathrm{O}_{4} /$ nanocarbon hybrids for electrocatalytic oxygen reduction and evolution. ACS. Appl. Mater. Interfaces 2014, 6, 12684-12691. [CrossRef] [PubMed]

5. Xu, S.; Kim, Y.; Park, J.; Higgins, D.; Shen, S.J.; Schindler, P. Extending the limits of Pt/c catalysts with passivation-gas-incorporated atomic layer deposition. Nat. Cat. 2018, 1, 624-630. [CrossRef]

6. Rosli, N.F.; Carmen, C.; Martinez, M.; Latiff, N.M. Layered PtTe 2 Matches Electrocatalytic Performance of $\mathrm{Pt} / \mathrm{C}$ for Oxygen Reduction Reaction with Significantly Lower Toxicity. ACS. Sustain. Chem. Eng. 2018, 6, 7432-7441. [CrossRef]

7. Whittingham, M.S. Lithium batteries and cathode materials. Chem. Rev. 2018, 104, 4271-4302. [CrossRef]

8. Morozan, A.; Campidelli, S.; Filoramo, A.; Jousselme, B.; Palacin, S. Catalytic activity of cobalt and iron phthalocyanines or porphyrins supported on different carbon nanotubes towards oxygen reduction reaction. Carbon 2011, 49, 4839-4847. [CrossRef]

9. Özer, L.M.; Altındal, A.; Özkaya, A.R.; Salih, B.; Bekaroglu, Ö. Synthesis, characterization, OFET and electrochemical properties of novel dimeric metallophthalocyanines. Dalton. Trans. 2013, 42, 6633-6644. [CrossRef]

10. Zhang, R.L.; Wang, J.; Xu, B.; Huang, X.Y.; Xu, Z.; Zhao, J.S. Investigation of binuclear metal phthalocyanines as electrocatalysts for Li/SOCl${ }_{2}$ battery. J. Electrochem. Soc. 2012, 159, H704-H710. [CrossRef]

11. Moraes, F.C.; Cabral, M.F.; Machado, S.A.; Mascaro, L.H. Electrocatalytic Behavior of Glassy Carbon Electrodes Modified with Multiwalled Carbon Nanotubes and Cobalt Phthalocyanine for Selective Analysis of Dopamine in Presence of Ascorbic Acid. Electroanalysis 2008, 20, 851-857. [CrossRef] 
12. Odabaş, Z.; Altındal, A.; Özkaya, A.R.; Salih, B.; Bekaroglu, Ö. Novel ball-type homo-and hetero-binuclear phthalocyanines with four 1, 10- methylenedinaphthalen-2-ol bridges: Synthesis and characterization, electrical and gas sensing properties and electrocatalytic performance towards oxygen reduction. Sens. Actuators B Chem. 2010, 145, 355-366. [CrossRef]

13. Hyun, K.; Ueno, T.; Panomsuwan, G.; Li, O.L.; Saito, N. Heterocarbon nanosheets incorporating iron phthalocyanine for oxygen reduction reaction in both alkaline and acidic media. Phys. Chem. Chem. Phys. 2016, 18, 10856-10863. [CrossRef] [PubMed]

14. Xu, G.F.; Li, Z.F.; Wang, S. Planar polyphthalocyanine cobalt absorbed on carbon black as stable electrocatalysts for direct methanol fuel cell. J. Power. Sources 2010, 195, 4731-4735. [CrossRef]

15. Chen, J.M.; Zou, K.Y.; Ding, P.; Deng, J. Conjugated Cobalt Polyphthalocyanine as the Elastic and Reprocessable Catalyst for Flexible Li-CO 2 Batteries. Adv. Mater. 2018, 31, 1805484. [CrossRef] [PubMed]

16. Gu, J.Y.; Cai, Z.F.; Wang, D. Single molecular imaging of Iron-Phthalocyanine catalyzed oxygen reduction reaction by in situ scanning tunneling microscopy. ACS Nano 2016, 10, 8746-8750. [CrossRef] [PubMed]

17. Xu, Z.W.; Kang, L.; Wang, R.Y.; Duan, X.T.; Liu, Q.Q.; Zhang, R.L. Electrochemical Effects of Lithium-Thionyl Chloride Battery by Central Metal Ions of Phthalocyanines-Tetraacetamide Complexes. J. Electrochem. Soc. 2017, 164, A3628-A3632. [CrossRef]

18. Peng, Y.X.; Li, Z.P.; Xia, D.G.; Zheng, L.R.; Liao, Y.; Li, K. Probing the influence of the center atom coordination structure in iron phthalocyanine multi-walled carbon nanotube-based oxygen reduction reaction catalysts by X-ray absorption fine structure spectroscopy. J. Power. Sources 2015, 291, 20-28. [CrossRef]

19. Li, T.; Peng, Y.; Li, K.; Zhang, R.; Zheng, L.; Xia, D. Enhanced activity and stability of binuclear iron (III) phthalocyanine on graphene nanosheets for electrocatalytic oxygen reduction in acid. J. Power. Sources 2015, 293, 511-518. [CrossRef]

20. Yasemin, C.; Emel, E.; Fatih, D.; Ali, R.Ö.; Bekir, S.; Özer, B. Synthesis, characterization, electrochemistry and VOC sensingproperties of novel ball-type dinuclear metallophthalocyanines. Sens. Actuators B 2014, 202, 1137-1147.

21. Kakı, E.; Altındal, A.; Salih, B.; Bekaroğlu, Ö. Synthesis, characterization and gas sensing properties of novel homo and hetero binuclear ball-type phthalocyanines. Dalton. Trans. 2015, 44, 8293-8299.

22. Tolbin, A.Y.; Ivanov, A.V.; Tomilova, L.G.; Zefirov, N.S. Synthesis of 1,2-bis(3,4-dicyanophenoxymethyl)benzene and binuclear zinc phthalocyaninesof clamshell and ball types. J. Porphyr. Phthalocyan 2003, 7, 162-166. [CrossRef]

23. Tolbin, A.Y.; Ivanov, A.V.; Tomilova, L.G.; Zefirov, N.S. Preparation of 1,2-bis(3,4-dicyanophenoxymethyl)benzene and the binuclear zinc phthalocyaninederived from it. Mendeleev. Commun. 2002, 12, 96-97. [CrossRef]

24. Bekaro־glu, Ö.; Jiang, J. Functional Phthalocyanine Molecular Materials; Springer: Berlin/Heidelberg, Germany, 2010; Volume 135, pp. 105-136.

25. Git, N.K.; Özen, Ü.E.; Özer, M.; Salih, B.; Özkaya, A.R.; Glu, Ö.B. Electrocatalytic Activity of Novel Ball-Type Metallophthalocyanines with Trifluoro Methyl Linkages in Oxygen Reduction Reaction and Application as Zn-Air Battery Cathode Catalyst. Electrochim. Acta 2017, 233, 237-248.

26. Beck, F.; Dammert, W.; Beiss, J.; Hiller, H.; Tolster, R. Electrocatalysis of oxygen cathode by metal-phthalocyanine and metal-dibenzotetraazaannulene. Z. Naturforsch. 1973, 28, 1009-1021.

27. Oliveira, M.A.C.; Mecheri, B.; D’Epifanio, A.; Placidi, E.; Arciprete, F.; Valentini, F. Graphene oxide nanoplatforms to enhance catalytic performance of iron phthalocyanine for oxygen reduction reaction in bioelectrochemical systems. J. Power. Sources. 2017, 356, 381-388. [CrossRef]

28. Liu, X.M.; Xu, T.; Li, Y.L.; Zang, Z.G.; Peng, X.S.; Wei, H.Y. Enhanced X-ray photon response in solution-synthesized $\mathrm{CsPBr}_{3}$ nanoparticles wrapped by reduced graphene oxide. Sol. Energy Mater. Sol. Cells 2018, 187, 249-254. [CrossRef]

29. Liu, L.; Zheng, K.; Yan, Y.; Cai, Z.H.; Lin, S.X.; Hu, X.B. Graphene Aerogels Enhanced Phase Change Materials prepared by one-pot method with high thermal conductivity and large latent energy storage. Sol. Energy Mater. Sol. Cells 2018, 185, 487-493. [CrossRef]

30. Kusuma, J.; Balakrishna, R.G.; Patil, S.; Jyothi, M.S.; Chandan, H.R.; Shwetharani, R. Exploration of Graphene oxide nanoribbons as excellent electron conducting network for third generation solar cells. Sol. Energy Mater. Sol. Cells 2018, 183, 211-219. [CrossRef] 
31. Dai, L.M.; Chang, D.W.; Baek, J.B.; Lu, W. Carbon Nanomaterials for Advanced Energy Conversion and Storage. Small 2012, 8, 1130-1166. [CrossRef]

32. Cui, L.; Lv, G.; Dou, Z. Fabrication of iron phthalocyanine/Graphene micro/nanocomposite by solvothermally assisted $\pi-\pi$ assembling method and its application for oxygen reduction reaction. Electrochim. Acta 2013, 106, 272-278. [CrossRef]

33. Zhang, X.; Feng, Y.; Tang, S.; Feng, W. Preparation of a Graphene oxide-phthalocyanine hybrid through strong $\pi-\pi$ interactions. Carbon 2010, 48, 211-216. [CrossRef]

34. Zhang, G.; Liu, B.L.; Zhou, H.W.; Yang, Y.; Chen, W.X.; Zhao, J.S. Graphene Wrapped Phthalocyanine: Enhanced Oxidative Desulfurization for Dibenzothiophene in Fuel. Appl. Organometallic. Chem. 2018, 32, a4477. [CrossRef]

35. Liu, D.; Peng, J.H.; Li, Z.Y.; Liu, B.; Wang, L. Improvement in the mechanical properties, proton conductivity, and methanol resistance of highly branched sulfonated poly(arylene ether)/Graphene oxide Grafted with flexible alkylsulfonated side chains nanocomposite membranes. J. Power. Sources 2018, 378, 451-459. [CrossRef]

36. Zhang, Y.; Wu, H.K.; Zhao, W.; Li, X.M.; Yin, R.; Qian, L. Iron (II) phthalocyanine nanoclusters - Graphene sandwich composite for oxygen reduction reaction catalysts. Mater. Des. 2017, 130, 366-372. [CrossRef]

37. Cao, R.G.; Thapa, R.; Kim, H.; Xu, X.D.; Kim, M.G.; Li, Q. Promotion of oxygen reduction by a bio-inspired tethered iron phthalocyanine carbon nanotube-based catalyst. Nat. Commun. 2013, 4, 2076. [CrossRef]

38. Järvinen, P.; Sampsa, K.; Hämäläinen, M.; Harju, A. Self-Assembly and Orbital Imaging of Metal Phthalocyanines on a Graphene Model Surface. J. Phys. Chem. C 2014, 118, 13320-13325. [CrossRef]

39. Serov, A.; Artyushkova, K.; Andersen, N.I. Original Mechanochemical Synthesis of Non-Platinum Group Metals Oxygen Reduction Reaction Catalysts Assisted by Sacrificial Support Method. Electrochim. Acta 2015, 179, 154-160. [CrossRef]

40. Jaouen, F.; Herranz, J.; Lefèvre, M. Cross-Laboratory Experimental Study of Non-Noble-Metal Electrocatalysts for the Oxygen Reduction Reaction. ACS. Appl. Mater. Interfaces 2009, 1, 1623-1639. [CrossRef]

41. Jin, H.G.; Jiang, X.; Irina, A.; Clair, S.; Valérie, M.; Chendo, C. Microwave-mediated synthesis of bulky lanthanide porphyrin-phthalocyanine triple-deckers: Electrochemical and magnetic properties. ACS Inorg. Chem. 2017, 6, b03056. [CrossRef]

42. Tejerina, L.; Nazeeruddin, M.K.; GRätzel, M.; Torres, T. Role of the bulky aryloxy Group at the non-peripheral position of phthalocyanines for dye sensitized solar cells. ChemPlusChem 2017, 82, 132-135. [CrossRef] [PubMed]

43. Chen, R.; Li, H.; Chu, D. Unraveling Oxygen Reduction Reaction Mechanisms on Carbon-Supported Fe-Phthalocyanine and Co-Phthalocyanine Catalysts in Alkaline Solutions. J. Phys. Chem. C 2009, 113, 20689-20697. [CrossRef]

44. Guo, J.; He, H.; Chu, D. OH-Binding Effects on Metallophthalocyanine Catalysts for $\mathrm{O}_{2}$, Reduction Reaction in Anion Exchange Membrane Fuel Cells. Electrocatalysis 2012, 3, 252-264. [CrossRef]

45. Oberst, J.L.; Thorum, M.S.; Gewirth, A.A. Effect of $\mathrm{pH}$ and Azide on the Oxygen Reduction Reaction with a Pyrolyzed Fe Phthalocyanine Catalyst. J. Phys. Chem. C 2018, 116, 25257-25261. [CrossRef]

46. Özen, Ü.E.; Elvan, D.; Özer, M.; Glu, Ö.B.; Özkaya, A.R. Communication-High-Performance and Non-Precious Bifunctional Oxygen Electrocatalysis with Binuclear Ball-Type Phthalocyanine Based Complexes for Zinc-Air Batteries. J. Electrochem. Soc. 2016, 163, A2001-A2003. [CrossRef]

47. Tanaka, A.; Fierro, C.; Scherson, D.; Yaeger, E. Electrocatalytic aspects of iron phthalocyanine and its. mu.-oxo derivatives dispersed on high surface area carbon. J. Phys. Chem. 1987, 91, 3799-3807. [CrossRef]

(C) 2020 by the authors. Licensee MDPI, Basel, Switzerland. This article is an open access article distributed under the terms and conditions of the Creative Commons Attribution (CC BY) license (http://creativecommons.org/licenses/by/4.0/). 